\title{
Bio-acidification and enhanced crusting as an alternative to sulphuric acid addition to slurry to mitigate ammonia and greenhouse gases emissions during short term storage
}

\author{
Joana Prado ${ }^{\text {a, João Chieppe }}{ }^{\mathrm{b}}$, Anabela Raymundo ${ }^{\mathrm{a}}$, David Fangueiro ${ }^{\mathrm{a},{ }^{*}}$ \\ a LEAF, Instituto Superior de Agronomia, Universidade de Lisboa, Tapada da Ajuda, 1349-017, Lisboa, Portugal \\ ${ }^{\mathrm{b}}$ Instituto Federal de Educação Ciência e Tecnologia de Goiás (IFG), Campus Inhumas, GO, Brazil
}

\section{A R T I C L E I N F O}

\section{Article history:}

Received 24 January 2020

Received in revised form

24 March 2020

Accepted 29 March 2020

Available online 9 April 2020

Handling Editor: Cecilia Maria Villas Bôas de Almeida

\section{Keywords:}

Slurry

Bio-acidification

Crust formation

Cheese whey

Sugar

Rice bran

\begin{abstract}
A B S T R A C T
Several solutions are today proposed to farmers to minimize ammonia $\left(\mathrm{NH}_{3}\right)$ emissions during storage. In the present study, special attention was given to slurry acidification and slurry crust enhancement and our objective was to assess the effect of slurry bio-acidification using sugar and cheese whey as an alternative to sulphuric acid, and the potential of rice bran as crust enhancer on $\mathrm{NH}_{3}$ and greenhouse gases emissions during storage. Both the cheese whey and the rice bran are materials, available in large amounts, with low commercial value in some EU regions as Portugal and its use, at farm scale, will be a win-win situation. Sugar is also a good alternative to acid attending its relatively low value. A laboratory experiment was performed for 2 months with five treatments: non-treated cattle slurry (CTRL), slurry treated with sulphuric acid (ACID), slurry treated with sugar (SUGAR), slurry treated with cheese whey (WHEY) and rice bran applied on the slurry surface (RICE). The SUGAR treatment led to a reduction of $\mathrm{NH}_{3}$ emissions by $45 \%$ relative to CTRL while WHEY and RICE resulted in a reduction of $68 \%$ and $25 \%$, respectively. Nevertheless, this effect of SUGAR and WHEY was shorter than in ACID, since $\mathrm{NH}_{3}$ emissions started to be observed in those 2 treatments after 31 and 35 days of storage, respectively. Nitrous oxide emissions remained close to zero in ACID and SUGAR. RICE led to the highest emissions of carbon dioxide $\left(\mathrm{CO}_{2}\right)$ releasing almost $5 \%$ of carbon present in the initial mixture (slurry + rice bran) and presented the highest methane emissions. The ACID and SUGAR led to a significant decrease of the total greenhouse gas (GHG) emissions. Our results indicate that bio-acidification using a source of sugar could be a good alternative to $\mathrm{H}_{2} \mathrm{SO}_{4}$ to reduce simultaneously $\mathrm{NH}_{3}$ and $\mathrm{GHG}$ emissions during storage.
\end{abstract}

(C) 2020 Elsevier Ltd. All rights reserved.

\section{Introduction}

The worldwide population should increase by $33 \%$ until 2050 (UN, 2013), while the demand for agricultural products should increase by 70\% (Eise and Foster, 2009). Namely, a "livestock revolution" should occur in developing countries (Wright et al., 2012) due to the growing demand for milk and meat products (Alexandratos and Bruinsma, 2012). To attend the consumers' demand, the livestock production needed to be more productive and the extensive production tends to be replaced by an intensive production concentrated in small areas (Malomo et al., 2018). The environmental impacts associated with this intensification of the

\footnotetext{
* Corresponding author.

E-mail address: dfangueiro@isa.ulisboa.pt (D. Fangueiro).
}

livestock production are diverse (Leip et al., 2015), but its impact on global warming is one of the main concerns since the livestock sector contributes to $14.5 \%$ of the global greenhouse gases (GHG) emissions (Gerber et al., 2013).

The high production of manure, namely slurry (liquid manure) induced by the intensification of livestock production has a strong impact on the environment: manure management represents $9.5 \%$ of global emissions from livestock sector (Gerber et al., 2013) and even though ammonia $\left(\mathrm{NH}_{3}\right)$ is not a GHG, $80 \%$ of the total ammonia emissions in agriculture comes from livestock (Petersen et al., 2012). The emissions of $\mathrm{NH}_{3}$ (Anderson et al., 2003), nitrous oxide $\left(\mathrm{N}_{2} \mathrm{O}\right)$ and methane $\left(\mathrm{CH}_{4}\right)$ from slurry are influenced by a wide range of factors as the nitrogen $(\mathrm{N})$ content of the animal feed, the animal species and storage conditions (Amon et al., 2006). $\mathrm{NH}_{3}$ emission occurs naturally during slurry storage and the emission rate is ruled by the ratio ammonium:ammonia $\left(\mathrm{NH}_{4}^{+}: \mathrm{NH}_{3}\right)$ existing 
at the slurry surface (Ni, 1999).

Hou et al. (2017) recently reviewed the impact of 12 mitigations solutions on $\mathrm{NH}_{3}$ and GHG emissions from animal manure. Solutions to minimize $\mathrm{NH}_{3}$ emissions act at three levels: 1 ) reduction of the amount of $\mathrm{NH}_{4}^{+}$and $\mathrm{NH}_{3}$ in the slurry by diet manipulation (Adegbeye et al., 2019); 2) decrease of the diffusion of $\mathrm{NH}_{3}$ at the slurry-air interface through the presence of natural crusts or floating covers (Van der Zaag et al., 2008) or by addition of biochar (Schmidt, 2014); 3) lowering of the slurry $\mathrm{pH}$ to increase the $\left(\mathrm{NH}_{4}^{+}: \mathrm{NH}_{3}\right)$ ratio (Fangueiro et al., 2015a). Alternatively, animal manure can be used to produce biogas (Krause and Rotter, 2018) or Biochar (Maroušek et al., 2019) with a direct impact on $\mathrm{NH}_{3}$ emissions during storage. The implementation of these solutions represents an extra cost to farmers and their efficiency depends on several parameters namely slurry composition (Petersen, 2018). Furthermore, some of these solutions, useful to minimize $\mathrm{NH}_{3}$ emissions, might also increase or decrease $\mathrm{N}_{2} \mathrm{O}$ and $\mathrm{CH}_{4}$ emissions (Hou et al., 2017).

Slurry acidification using sulphuric acid (Sokolov et al., 2020), is used at farm scale in several countries from North and East Europe and is also starting to be applied at industrial scale in Spain (Rodhe et al., 2018). Nevertheless, all the safety issues related to $\mathrm{H}_{2} \mathrm{SO}_{4}$ handling were identified as the main limitations in the implementation of such solutions (Regueiro et al., 2016a). Alternatives to the use of sulphuric acid are therefore required. Recently, bioacidification of slurry using sucrose has been successfully tested (Piveteau et al., 2017). However, as referred by Piveteau et al. (2017), the addition of labile carbon to slurry might enhance methane emissions during storage. Another option to be considered for bioacidification of dairy slurry could be the use of sub-products from the dairy industry. Cheese whey is today considered a waste by cheese factory that needs to have some storage tanks and then dry it or pay for its removal (Malaspina et al., 1995). Large amounts of whey are produced worldwide. In Portugal, annually, around $70000 t$ of cheese are produced, corresponding to 633 million litters of whey (1 kg Cheese/9LWhey) (Faostat, 2015a, 2015b) containing $50 \%$ of the milk nutrients: soluble protein, lactose, vitamins and minerals. It has been considered a relevant pollutant, but few strategies have been developed to add-value to whey. A combined storage of cattle slurry and cheese whey followed by application to soil as organic fertilizers could be beneficial if the cheese whey could reduce slurry $\mathrm{pH}$ and consequently ammonia emissions. As occur with sugar, the addition of cheese whey might impact the emission of GHG emissions during storage and such impact need to be estimated before implementation at farm scale.

Crusting enhancement at the slurry surface is a solution easy to implement at farm scale but that can represent a significant cost if it does not increase the slurry fertilizer value. Hence, the use of available and free agricultural by-products rich in nutrients is the easiest way to promote such a solution. Besides, it also allows to improve the reuse of natural resource in line with EU recommendation and might increase the slurry fertilizing value. The rice bran can be used as a supplement for animal feed and food applications, but its storage implies some specific conditions to avoid fermentation and lipidic degradation (Pereira et al., 2019). Hence in many cases, rice producers do not valorise rice bran, since it is necessary to carry out a stabilization step. Since this material is rich in nitrogen and its structure adapted for crust formation, we hypothesized that it could be used to enhance slurry crust formation during storage.

The aim of the present work was to estimate the potential use of new additives to reduce ammonia emissions from slurry stores and assess its impact on carbon dioxide $\left(\mathrm{CO}_{2}\right), \mathrm{CH}_{4}$ and $\mathrm{N}_{2} \mathrm{O}$ emissions and global warming potential (GWP).

\section{Materials and methods}

\subsection{Slurry and additives}

The slurry used was sampled at a commercial dairy farm with an intensive production. Animals were fed with maize and grass silage and received a complement of about $8 \mathrm{~kg}$ of concentrated feed. The slurry was automatically scrapped to a central slurry pit every $4 \mathrm{~h}$. The slurry was sampled directly from the central pit and stored in plastic barrels loosely closed during 3 weeks before the beginning of the storage experiment at ambient temperature.

The cheese whey was sampled in a cheese factory (Queijos Santiago, SA) and was stored at $4{ }^{\circ} \mathrm{C}$ in plastic barrels until used, to prevent its fermentation.

The rice bran was supplied by a rice producer association (Aparroz) and was sampled in the main storage building and kept at ambient temperature until used.

The source of sucrose used here was commercial table sugar purchased in a local supermarket.

The cheese whey had a $\mathrm{pH}$ of 4.8 , total carbon content of $41.77 \mathrm{~g} \mathrm{~kg}^{-1}$, total nitrogen content of $0.80 \mathrm{~g} \mathrm{~kg}^{-1}$, potassium content of $2.04 \mathrm{mg} \mathrm{kg}^{-1}$ and sodium content of $3.33 \mathrm{mg} \mathrm{kg}^{-1}$. The rice bran has a pH of 6.32 , total carbon content of $396.70 \mathrm{~g} \mathrm{~kg}^{-1}$ and $21.52 \mathrm{~g} \mathrm{~kg}^{-1}$ of total nitrogen. The slurries composition can be found in Table 1 .

\subsection{Analytical methods}

Dry matter content (DM) was determined by drying $10 \mathrm{~g}$ of fresh material in a heater at $105{ }^{\circ} \mathrm{C}$ to constant weight. Ash content was determined by incineration of $2 \mathrm{~g}$ of dry material at $550{ }^{\circ} \mathrm{C}$ for $3 \mathrm{~h}$. Total carbon was determined using a Total Carbon Analyser (TOC) (AnalityJena, EA4000). pH was determined directly in the slurry or slurry mixture (with additive) using a $\mathrm{pH}$ electrode connected to a potentiometer method (Orion 3 star). The Kjeldahl method was used to assess the total $\mathrm{N}$ and $\mathrm{NH}_{4}^{+}$content of the samples: $9 \mathrm{~g}$ were digested with $15 \mathrm{ml}_{\text {of }} \mathrm{H}_{2} \mathrm{SO}_{4}$ for $3 \mathrm{~h}$ in the case of the total $\mathrm{N}$, while the ammonium $\mathrm{N}$ content was determined directly.

$\mathrm{Mn}, \mathrm{Zn}, \mathrm{Cu}, \mathrm{Fe}, \mathrm{Ca}, \mathrm{Mg}$, $\mathrm{Na}$, $\mathrm{K}$ and $\mathrm{P}$ contents were quantified after hydrochloric acid $(\mathrm{HCl})$ treatment of the ash through graphite furnace atomic absorption spectrophotometry (Unicam M Series), except for phosphorous, which was determined using the ammonium vanadomolybdate method by molecular absorption spectrophotometry (Hitachi).

\subsection{Preliminary studies}

A first trial was performed to assess the potential use of sugar and cheese whey as a treatment for slurry acidification and to identify the amount of each additive needed to reach a $\mathrm{pH}$ value lower than 5.5. For each of these materials, several amounts were mixed with $500 \mathrm{~g}$ of dairy slurry in a $1 \mathrm{~L}$ jar; the amounts tested were $10 \mathrm{~g}, 20 \mathrm{~g}, 30 \mathrm{~g}$ and $40 \mathrm{~g}$ of sugar and $100 \mathrm{ml}, 150 \mathrm{ml}, 200 \mathrm{ml}$ and $250 \mathrm{ml}$ of cheese whey. The mixture was stirred manually, and the $\mathrm{pH}$ was measured over 14 days of storage, directly in the mixture using a pH electrode connected to a potentiometer (Aqua Lytic).

\subsection{Storage experiment}

The experiment took place indoors between July and September 2018 (62 days) with air temperatures varying between 22 and $33{ }^{\circ} \mathrm{C}$, similar to slurry storage conditions during summer in Portugal. The time duration of our study was based on published studies dealing with GHG emissions during storage of manure and other agricultural residues where time lengths from 50 to 80 days 
Table 1

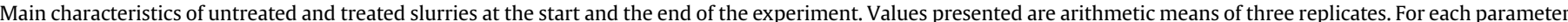

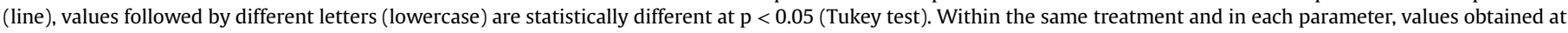
the start and end of the 62 days of storage are statistically different at $\mathrm{p}<0.05$ (Tukey test) when preceded by different letters (capital).

\begin{tabular}{|c|c|c|c|c|c|c|c|c|c|c|c|c|}
\hline & & \multirow[t]{2}{*}{ Slurry } & \multicolumn{2}{|l|}{ CTRL } & \multicolumn{2}{|l|}{ ACID } & \multicolumn{2}{|l|}{ SUGAR } & \multicolumn{2}{|l|}{ WHEY } & \multicolumn{2}{|l|}{ RICE } \\
\hline & & & Start & End & Start & End & Start & End & Start & End & Start & End \\
\hline $\mathrm{pH}$ & & $7.52^{\mathrm{a}}$ & & $6.58^{\mathrm{ab}}$ & & $5.82^{\mathrm{b}}$ & & $6.31^{\mathrm{b}}$ & & $6.74^{\mathrm{ab}}$ & & $6.76^{\mathrm{ab}}$ \\
\hline DM & $\mathrm{g} \mathrm{kg}^{-1}$ & $50.80^{c}$ & $\mathrm{~A}_{50,80}$ & ${ }^{B} 58,56^{c}$ & ${ }^{B} 50,80$ & ${ }^{A} 89.65^{b}$ & ${ }^{A} 87,31$ & ${ }^{A} 85.92^{b}$ & ${ }^{A} 62,22$ & ${ }^{B} 57.43^{c}$ & $\mathrm{~A}_{137,14}$ & ${ }^{\mathrm{A}} 142,32^{\mathrm{a}}$ \\
\hline $\mathrm{CT}$ & $\mathrm{g} \mathrm{kg}^{-1}$ & $21.95^{c}$ & ${ }^{\mathrm{A}} 21,95$ & ${ }^{\mathrm{A}} 24,71^{\mathrm{c}}$ & ${ }^{\mathrm{B}} 21,95$ & $\mathrm{~A}_{37.97^{\mathrm{b}}}$ & ${ }^{\mathrm{B}} 22,60$ & $\mathrm{~A}_{39.20^{\mathrm{b}}}$ & ${ }^{A} 28,55$ & ${ }^{A} 23.55^{c}$ & ${ }^{A} 56,02$ & ${ }^{\mathrm{A}} 58.37^{\mathrm{a}}$ \\
\hline $\mathrm{N}_{\mathrm{T}}$ & $\mathrm{g} \mathrm{kg}^{-1}$ & $2.44^{\mathrm{c}}$ & ${ }^{\mathrm{A}} 2,44$ & ${ }^{\mathrm{B}} 1.72^{\mathrm{d}}$ & ${ }^{\mathrm{B}} 2,44$ & ${ }^{A} 3.57^{\mathrm{a}}$ & $\mathrm{A}_{2,35}$ & ${ }^{A} 2.43^{c}$ & $\mathrm{~A}_{1,89}$ & ${ }^{\mathrm{B}} 1.56^{\mathrm{d}}$ & ${ }^{\mathrm{B}} 4,17$ & ${ }^{A} 5.18^{a}$ \\
\hline $\mathrm{NH}_{4}^{+}$ & $\mathrm{g} \mathrm{kg}^{-1}$ & $1.08^{c}$ & $\mathrm{~A}_{1,08}$ & ${ }^{\mathrm{B}} 0.65^{\mathrm{d}}$ & ${ }^{\mathrm{B}} 1,08$ & ${ }^{\mathrm{A}} 2.05^{\mathrm{b}}$ & ${ }^{\mathrm{A}} 1,04$ & ${ }^{\mathrm{B}} 0.84^{\mathrm{cd}}$ & ${ }^{\mathrm{A}} 0,74$ & ${ }^{\mathrm{A}} 0.59^{\mathrm{d}}$ & ${ }^{\mathrm{B}} 0,98$ & ${ }^{\mathrm{A}} 2.41^{\mathrm{a}}$ \\
\hline EC & $\mathrm{mS} \mathrm{cm}^{-1}$ & 1 & & $11.11^{\mathrm{b}}$ & & $19.09^{a}$ & & $12.21^{\mathrm{b}}$ & & $15.95^{\mathrm{ac}}$ & & $10.61^{\mathrm{b}}$ \\
\hline $\mathrm{P}$ & $\mathrm{g} \mathrm{kg}^{-1}$ & $0.45^{\mathrm{b}}$ & & $0.64^{\mathrm{b}}$ & & $0.65^{\mathrm{b}}$ & & $0.76^{\mathrm{b}}$ & & $0.45^{\mathrm{b}}$ & & $3.39^{\mathrm{a}}$ \\
\hline K & $\mathrm{g} \mathrm{kg}^{-1}$ & $1.19^{c}$ & & $2.28^{\mathrm{b}}$ & & $2.42^{\mathrm{b}}$ & & $2.05^{b}$ & & $1.92^{\mathrm{b}}$ & & $4.25^{\mathrm{a}}$ \\
\hline $\mathrm{Na}$ & $\mathrm{mg} \mathrm{kg}^{-1}$ & $0.42^{\mathrm{d}}$ & & $1.07^{\mathrm{bc}}$ & & $1.07^{\mathrm{bc}}$ & & $0.82^{\mathrm{c}}$ & & $1.65^{\mathrm{a}}$ & & $1.13^{\mathrm{b}}$ \\
\hline $\mathrm{Mg}$ & $\mathrm{mg} \mathrm{kg}^{-1}$ & $0.74^{\mathrm{b}}$ & & $0.85^{\mathrm{b}}$ & & $1.07^{\mathrm{b}}$ & & $0.82^{\mathrm{b}}$ & & $1.65^{\mathrm{b}}$ & & $1.13^{\mathrm{a}}$ \\
\hline
\end{tabular}

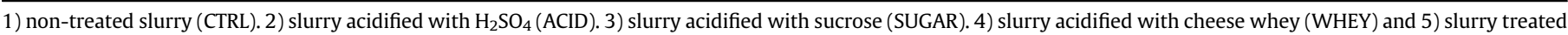
with rice bran (RICE).

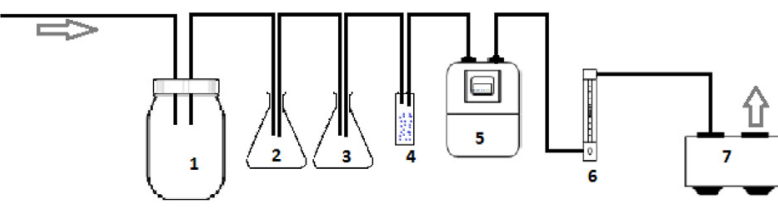

Fig. 1. Schematic representation of the model used to measure ammonia emissions, based on the method described by Hassouna et al. (2017) (1. The reactor; 2. Orthophosphoric acid; 3. Water; 4. Silica; 5. Gas Meter; 6. Flowmeter; 7. Pump).

were considered (Petersen et al., 2014; Regueiro et al., 2016b; Fangueiro et al., 2008).

The following treatments were considered: i) non-treated slurry (CTRL), ii) slurry treated with $\mathrm{H}_{2} \mathrm{SO}_{4}$ (ACID), iii) slurry treated with sucrose (SUGAR), iv) slurry treated with cheese whey (WHEY) and v) rice bran applied on the slurry surface (RICE). Each treatment was 3 times replicated.

For each treatment, $2 \mathrm{~kg}$ of non-treated slurry were weighed in a 5L jars equipped with a special lid to allow GHG measurements and to keep a constant airflow. An adequate amount of additive was mixed with the slurry in order to reach a final $\mathrm{pH}$ close or lower than 5.5: $12 \mathrm{ml}$ of concentrated sulphuric acid $\left(\mathrm{H}_{2} \mathrm{SO}_{4}\right)$ was added in ACID, $80 \mathrm{~g}$ of sugar in SUGAR and $1 \mathrm{~L}$ of cheese whey in WHEY. After adding the materials, the mixtures were stirred manually. In RICE treatment, $200 \mathrm{~g}$ of rice bran was added at the slurry surface, making a crust with $2 \mathrm{~cm}$.

Each jar was closed at the beginning of the experiment creating a headspace of $3 \mathrm{~L}$ in the case of CTRL, ACID, SUGAR and RICE and $2 \mathrm{~L}$ in the case of WHEY between the surface of the slurry and the lid.

Each jar lid was equipped with an air inlet and an air outlet similar to the device used by Fangueiro et al. (2008). The air inlet was connected to a PVC tube that captured clean air outside the experiment room. The air outlet was connected to a vacuum air pump to establish a continuous airflow $\left(2-31 \mathrm{~min}^{-1}\right)$ through the jar that ensured approximately one air exchange per minute in each jar. For this, a flow controller (Dwyer RMA-21-SS) was installed between the jar and the air pump.

A device, based on the model proposed by Hassouna et al. (2017), was used to continuously trap the emitted ammonia (Fig. 1): a first Erlenmeyer flask containing $200 \mathrm{ml}$ of orthophosphoric acid $0.1 \mathrm{~N}$ was used to trap the ammonia present in the air coming from the jar, a second Erlenmeyer flask containing water to remove any acid present in the air, which afterwards passed through a recipient containing silica, to absorb the humidity present in the air. To measure accurately the volume of air flowing through the jar, a gas meter (Itron Gallus, G4) was connected to each jar.

After each measurement period, the orthophosphoric acid contained in each trap was analysed by automated segmented-flow spectrophotometric methods (Houba et al., 2000) to assess the $\mathrm{NH}_{4}^{+}$ concentration in the solution. Ammonia emissions were measured $4 \mathrm{~h} \mathrm{~d}^{-1}$ in the first day, $17 \mathrm{~h} \mathrm{~d}^{-1}$ in the second day and $22 \mathrm{~h} \mathrm{~d}^{-1}$ onward.

$\mathrm{CH}_{4}, \mathrm{CO}_{2}$ and $\mathrm{N}_{2} \mathrm{O}$ emissions were assessed using the closed system method described in Fangueiro et al. (2015b). Briefly, the airflow was stopped, and the air inlet and outlet were closed. Air sampling inside the jar was then performed through the sampling port immediately after closure $\left(\mathrm{T}_{0}\right)$, after $20 \mathrm{~min}\left(\mathrm{~T}_{1}\right)$ and after $40 \min \left(\mathrm{T}_{2}\right)$. The fluxes were calculated by fitting linear regressions through the data collected at $T_{0}, T_{1}$ and $T_{2}$ and then corrected for temperature.

The concentrations of the gas samples stored in vials were measured by gas chromatography (GC) using a GC-2014 (Shimadzu, Japan) equipped with an electron capture $63 \mathrm{Ni}$ detector for $\mathrm{N}_{2} \mathrm{O}$, a thermal conductivity detector for $\mathrm{CO}_{2}$ and a flame ionization detector for $\mathrm{CH}_{4}$. Emissions of $\mathrm{N}_{2} \mathrm{O}, \mathrm{CH}_{4}$ and $\mathrm{CO}_{2}$ were measured every two days, except during the weekends where measurements were not performed.

At the end of the experiment, after the 62 days of storage, the material in each jar was stirred to obtain a homogeneous mixture and some samples were collected and stored at $4{ }^{\circ} \mathrm{C}$ prior to analysis.

\subsection{Calculation and statistical analysis}

Cumulative emissions were estimated by averaging the flux between two sampling measurement period and multiplying by the time interval between the measurements. These values of cumulative emissions were scaled by the total amount of material in the jar (including additives): $2000 \mathrm{~g}$ in CTRL, $2012 \mathrm{~g}$ in ACID, $2080 \mathrm{~g}$ in SUGAR, $3000 \mathrm{~g}$ in WHEY and $2200 \mathrm{~g}$ in RICE.

The Global Warming Potential (GWP), expressed as $\mathrm{CO}_{2}$ equivalents, was estimated from the $\mathrm{CH}_{4}$ and $\mathrm{N}_{2} \mathrm{O}$ emissions using the most recent GWP conversion factors for 100 -year time horizon equal to 28 for $\mathrm{CH}_{4}$ and to 245 for $\mathrm{N}_{2} \mathrm{O}$ (International Panel Climate Change, 2016).

All the results obtained were analysed by analysis of variance (one-way ANOVA) in order to evaluate the effects of each treatment using the software Statistix 7. To define the statistical significance of the mean and ascertain the effect of the treatments, a Tukey test 
was performed, with a level of significance at $\mathrm{p}<0.05$.

\section{Results and discussion}

\subsection{Impact of additives on slurry characteristics}

The reduction of the slurry $\mathrm{pH}$ to a value lower than 5.5 with the bio-acidification inhibit ammonia emissions (Fangueiro et al., 2015a). Preliminary studies using several amounts of cheese whey $\left(200,300,400\right.$ and $500 \mathrm{~g} \mathrm{~kg}^{-1}$ of slurry) and sugar $(20,40,60$, $80 \mathrm{~g} \mathrm{~kg}^{-1}$ of slurry) were performed here to assess the minimum amount needed to reach a $\mathrm{pH}$ value lower than 5.5 in the slurry mixture (Fig. 2A). The best results were obtained with an addition of $500 \mathrm{~g}$ of cheese whey per $\mathrm{kg}$ of slurry that allows keeping a $\mathrm{pH}$ value lower than 5.5 during several days of storage, as seen in Fig. 2B. It is still to note that a $\mathrm{pH}$ value $<5.5$ was reached only after 4 days of storage when using cheese whey. Regarding the use of sugar, as our preliminary results indicated an amount of $40 \mathrm{~g}$ per $\mathrm{kg}$ of slurry (Fig. 2A) was enough to reach a pH value of 5.5 in the slurry mixture, in agreement with results obtained by Piveteau et al. (2017) with this same additive. As seen in Fig. 2B, this amount of sugar ensured a slurry $\mathrm{pH}$ below 5.0 during more than 20 days of storage. This preliminary study allowed the conclusion that both cheese whey and sugar are good additives to be used for bioacidification of slurry.

The main characteristic of the raw slurry (before treatment) and the treated slurries after 62 days of storage are shown in Table 1. Some modifications of the composition of the non-treated slurry were observed after 62 days of storage, namely in terms of dry matter content with an increase from $50.8 \mathrm{~g} \mathrm{~kg}^{-1}$ to $69.5 \mathrm{~g} \mathrm{~kg}^{-1}$. This increase of DM content was due to the water evaporation that also explains the increase observed in the concentrations of most nutrients, except $\mathrm{NH}_{4}^{+}$. Indeed, the decrease of $\mathrm{NH}_{4}^{+}$concentration observed in the non-treated slurry (CTRL) is in agreement with the ammonia emissions described below in this treatment. Similarly, the decrease of $\mathrm{pH}$ from 7.52 to 6.58 in CTRL can also be attributed to $\mathrm{NH}_{3}$ emissions that led to the acidification of slurry and/or to the continuous microorganism's activity.
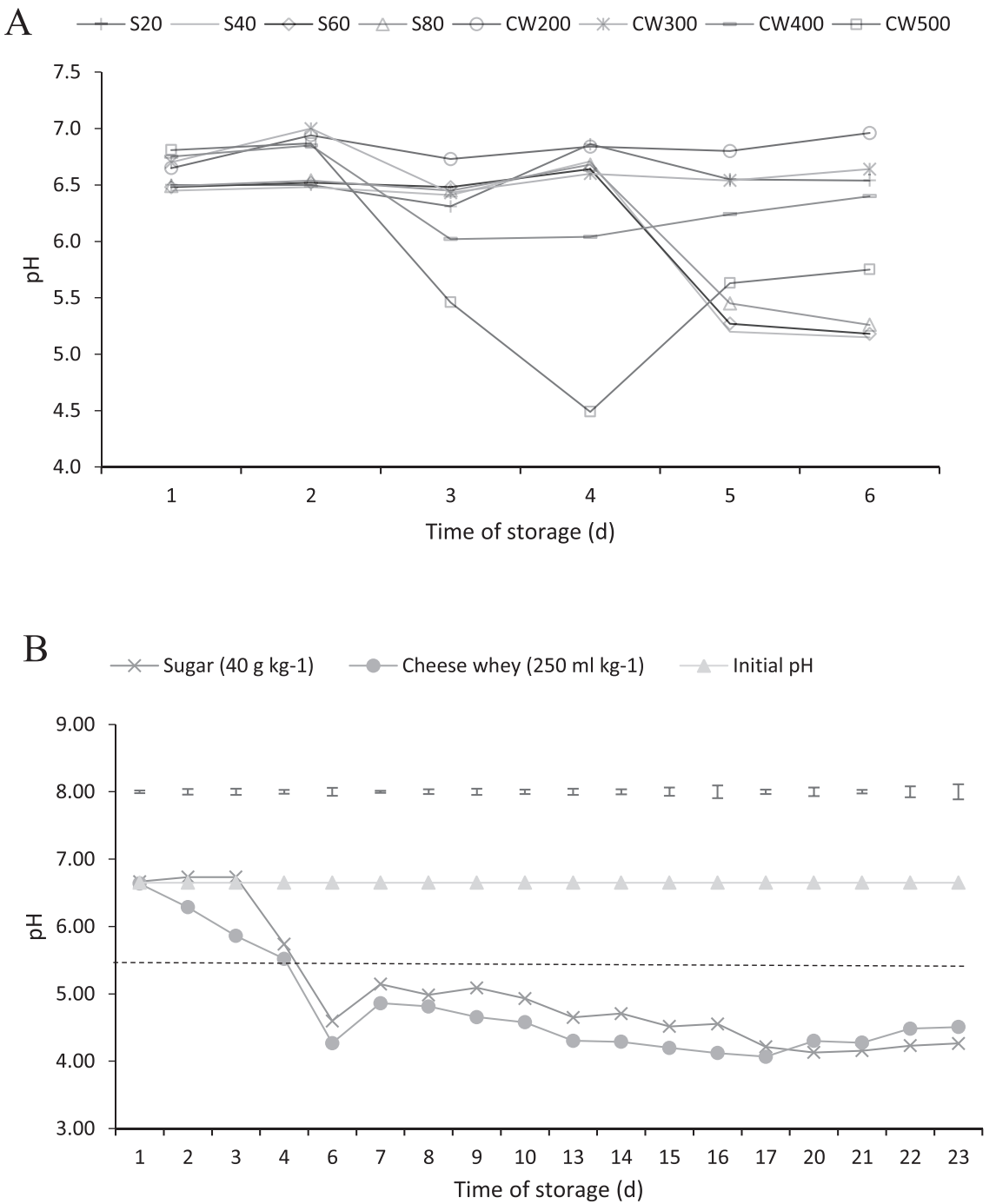

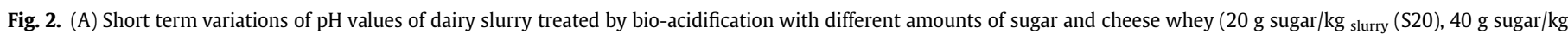

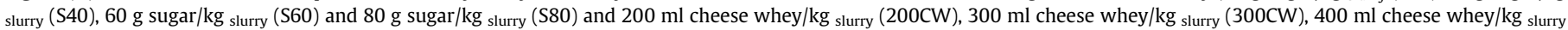

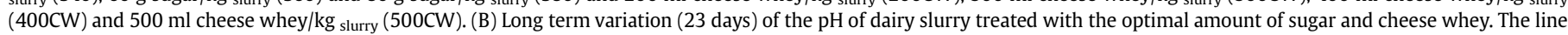

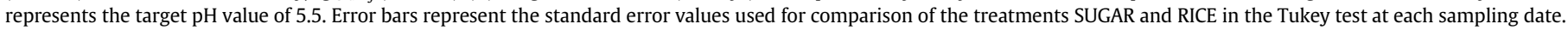


Considering the amount of sugar needed to reach $\mathrm{pH}<5.5$, bioacidification using a sucrose source will probably not be applied at farm scale using sugar as additive. Nevertheless, several subproducts rich in sucrose, namely from the yeast industry, might be used for such purpose. Similarly, the amount of cheese whey that has to be added to reach a $\mathrm{pH}<5.5$ is considerable and will imply some significant adaptation at farm scale (increase storage capacity). Nevertheless, cheese whey (as well as rice bran) are two agricultural sub-products that are currently not valorized and need to be reused since both contain an appreciable amount of $\mathrm{N}$ and $\mathrm{C}$.

A pH below 5.5 was reached in slurry treated with ACID, SUGAR and WHEY a few days after the addition of the additives. ACID was the only treatment that kept a pH lower than 6 (5.82) till the end of the experiment, while in all the other treatments the final $\mathrm{pH}$ was close to the value observed in CTRL. In terms of $\mathrm{NH}_{4}^{+}$, the positive effect of acidification with sulphuric acid reported by Fangueiro et al. (2015c) can also be noticed here since an increase of the $\mathrm{NH}_{4}^{+}$concentration was observed during storage as a result of DM increase and no (or residual) ammonia emission. The addition of rice bran led to an enrichment of slurry in $\mathrm{P}$ and $\mathrm{Mg}$ which can be seen as a positive effect if the slurry mixture is applied to soil and is used as a source of $\mathrm{P}$ or $\mathrm{Mg}$. On the other side, the addition of cheese whey led to an increase of $\mathrm{Na}$ content $\left(1.65 \mathrm{mg} \mathrm{kg}^{-1}\right)$ relative to CTRL (1.07 mg kg-1). Such amount of Na might be problematic if repeated applications of slurry treated with cheese whey are performed to the same parcel even if values remained lower than in the initial cheese whey. It is to refer that WHEY is rich in other nutrients which can enrich the slurry and enhance its agronomic value. Attending that cheese whey can not be applied directly to the soil, the mixture of slurry with cheese whey might be a solution to convert waste into a valuable agricultural amendment. Indeed, recent studies showed that cheese whey not only decreased $\mathrm{NH}_{3}$ emissions from animal slurry after soil application but also improve the agronomic value of the slurry (unpublished data).

\subsection{Ammonia emissions}

Daily rates of ammonia emission observed during storage of treated and non-treated slurry are shown in Fig. 3 (A). Ammonia emissions in CTRL peaked on day 8 and then decreased until day 17 and, at day 22, started again to increase. Over the first 20 days of storage, the slurry treatments applied reduced significantly $\mathrm{NH}_{3}$ emissions even if the effect of SUGAR was not immediate. Indeed, in sugar treatment, the $\mathrm{NH}_{3}$ emissions decreased gradually over the first 2 days of storage to reach values close to zero. Although the preliminary study indicated that the WHEY treatment also needed 4 days to reach the ideal $\mathrm{pH}$ of 5.5 , no ammonia emissions were detected during this time period.

After day 20, $\mathrm{NH}_{3}$ emissions in ACID, SUGAR and WHEY remained lower than in CTRL, even if $\mathrm{NH}_{3}$ emissions started to increase in SUGAR and WHEY treatment. Ammonia emissions in RICE started to increase on day 17 to reach emissions similar to CTRL on day 30 till the end of the experiment. It is still to refer that $\mathrm{NH}_{3}$ emissions in WHEY became higher than CTRL after day 32. From day 43 till the end of the experiment, daily emissions rates were similar in all treatments except in ACID where a stable and significantly lower rate was observed. The acidification with sulphuric acid only shows a slight increase in $\mathrm{NH}_{3}$ emissions on day 54 . The increase of $\mathrm{NH}_{3}$ emissions in SUGAR and WHEY might be due to the increase of $\mathrm{pH}$ as a consequence of microorganism activity. It is still to refer that the water losses observed in each treatment during the experiment might have influenced the ammonia emissions; more experiments at a large scale are needed to validate our results.

The highest cumulative $\mathrm{NH}_{3}$ emissions were observed in CTRL and RICE even if values were significantly different. The SUGAR and
WHEY treatments resulted both on the reduction of $\mathrm{NH}_{3}$ emissions relative to CTRL even if WHEY treatment was more efficient. Nevertheless, none of the treatments tested reduces the emissions to values comparable to ACID treatment (Table 2).

The addition of sugar to slurry led to acidogenesis that enables the natural acidification under anaerobic conditions. The acidogenesis process transforms organic matter into volatile fatty acids, lactic acid and alcohols by hydrolysis and fermentation (through fermenting bacteria) (Piveteau et al., 2017).

The cumulative emissions of $\mathrm{NH}_{3}$ were expressed as a \% of total $\mathrm{N}$ existing in the slurry only and in the mixture (slurry + additive) and as a \% of $\mathrm{NH}_{4}^{+}$existing in the slurry (Table 2). Total ammonia emissions in CTRL represent $38 \%$ of slurry total $\mathrm{N}$ and $87 \%$ of slurry $\mathrm{NH}_{4}^{+}$. The use of crusting with rice bran led to total $\mathrm{NH}_{3}$ emissions equivalent to $28 \%$ and $\sim 65 \%$ of slurry total $\mathrm{N}$ and slurry $\mathrm{NH}_{4}^{+}$, respectively.

Less than $1 \%$ of slurry total $\mathrm{N}$ was lost as $\mathrm{NH}_{3}$ in ACID while, in SUGAR and WHEY, ammonia losses represented 20 to $12 \%$ of slurry total $\mathrm{N}$ and 47 to $27 \%$ of slurry $\mathrm{NH}_{4}^{+}$.

The values observed in this experiment concerning the ACID, are higher than those observed in similar studies (Kai et al., 2008), where the decrease was close to $75 \%$ with pig slurry comparative to the non-treated slurry (Dai and Blanes-Vidal, 2013). However in studies done by Wang et al. (2014), the maximum efficiency reduction was $92 \%$ and Petersen et al. (2012) refer a decrease of 96-99\%, which are similar to the results present in this study $(99 \%$ efficiency compared to the CTRL emissions).

It is to note that in the RICE treatment, the total amount of $\mathrm{N}$ in the mixture was significantly higher than in the remaining treatments. Indeed, the rice bran, rich in $\mathrm{N}$, increase the total $\mathrm{N}$ content of the slurry and might have stimulated the $\mathrm{NH}_{3}$ emissions. The opposite effect was reported by Misselbrook et al. (2016), who observed a decrease of $12 \%$ of the slurry total $\mathrm{N}$ immediately after the addition of clay. As a consequence, when the $\mathrm{NH}_{3}$ losses were expressed based on the initial $\mathrm{N}$ content of the mixture, similar values were obtained in RICE, SUGAR and WHEY. Even if rice bran poorly prevents $\mathrm{NH}_{3}$ losses from slurry storage, its addition to slurry might contribute to increase the fertilizing value of slurry.

\subsection{Emissions of greenhouse gases}

\subsubsection{Nitrous oxide emissions}

Nitrous oxide is a sub-product of nitrification and/or denitrification. During slurry storage, $\mathrm{N}_{2} \mathrm{O}$ emissions are generally low due to limited nitrification imposed by anaerobic conditions (Loyon et al., 2007). Nevertheless, some nitrification/denitrification has been reported during manure storage by Berg et al. (2006) who found that $\mathrm{N}_{2} \mathrm{O}$ production occurs when a dry crust was present on the slurry. In the present study, $\mathrm{N}_{2} \mathrm{O}$ emissions remained close to zero in all treatments during the first 12 days (Fig. 3B). After this period, CTRL had a significantly different behaviour relative to other treatments. Indeed, a significant emission of $\mathrm{N}_{2} \mathrm{O}$ was observed in CTRL between day 12 and 26 , with a peak of $\sim 40 \mu \mathrm{g} \mathrm{N}_{2} \mathrm{O}-\mathrm{N}$ $\mathrm{kg}_{\text {mixture }}^{-1} \mathrm{~h}^{-1}$ reached on day 17 . Since no treatment was applied, the $\mathrm{NH}_{4}^{+}$nitrification in CTRL might have led to the emission of $\mathrm{N}_{2} \mathrm{O}$. In all other treatments, no $\mathrm{N}_{2} \mathrm{O}$ emissions were observed until day 38, where $\mathrm{N}_{2} \mathrm{O}$ emissions started to increase in WHEY and RICE. Similarly, some $\mathrm{N}_{2} \mathrm{O}$ emissions were also observed in CTRL from day 53-62. It is to refer that $\mathrm{N}_{2} \mathrm{O}$ emissions in ACID and SUGAR remained close to zero during all the experiment.

In both RICE and CTRL treatment, a crust was observed on slurry surface and such crust includes some aerobic zones in between the anaerobic parts. Therefore, these two treatments presented some favourable conditions for $\mathrm{N}_{2} \mathrm{O}$ and $\mathrm{CH}_{4}$ production. Indeed, the trends of $\mathrm{N}_{2} \mathrm{O}$ emissions observed in our study are in agreement 

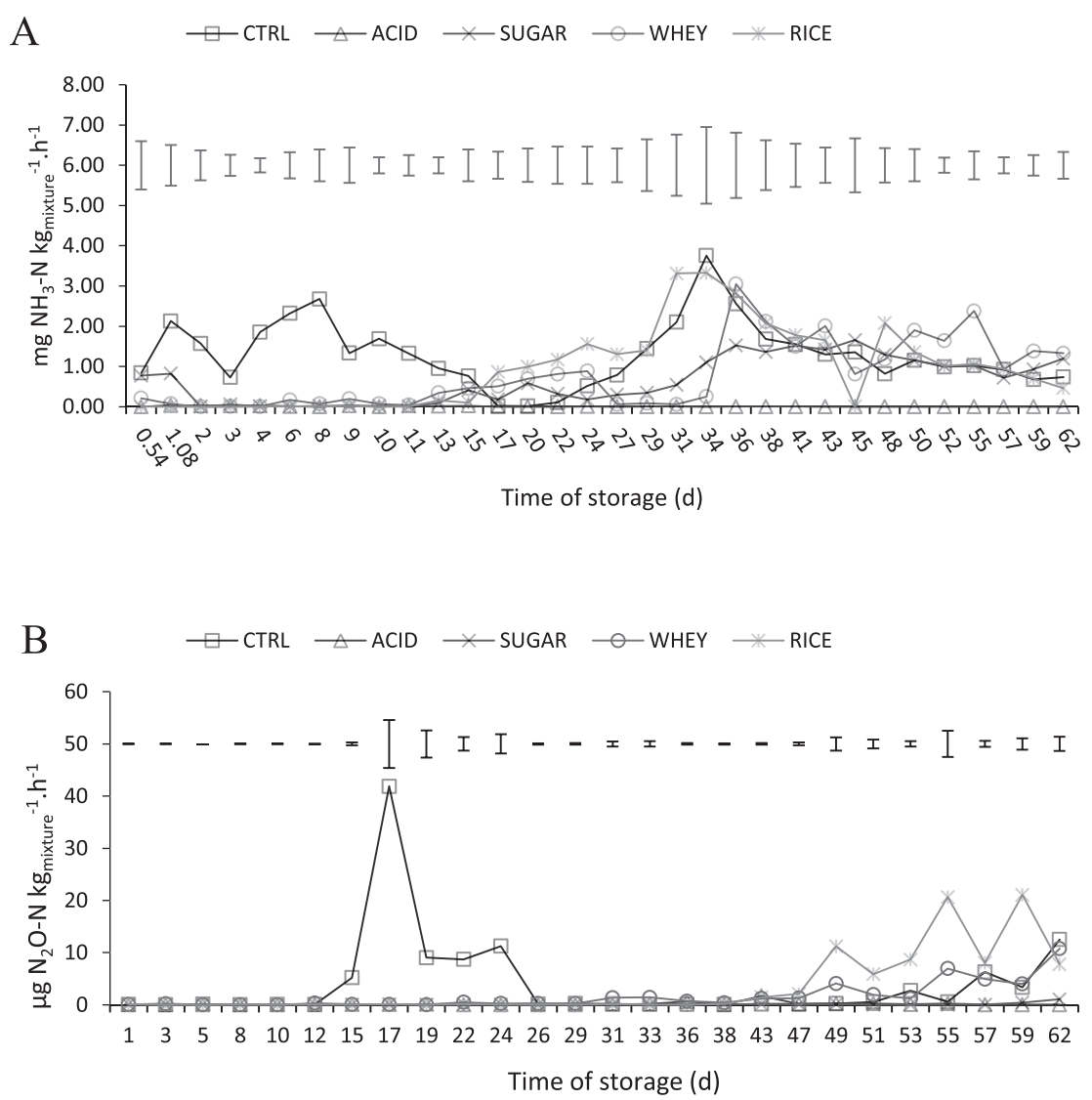

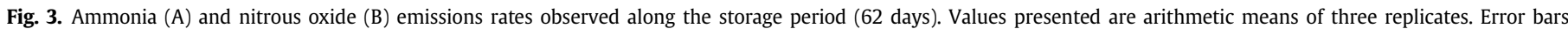
represent the standard error values used for comparison in the Tukey test at each sampling date.

\section{Table 2}

Values of cumulative nitrous oxide emission expressed as $\mu \mathrm{g} \mathrm{kg}_{\text {mixture }}^{-1}$ and cumulative ammonia emission expressed as $\mathrm{mg} \mathrm{kg}_{\text {mixture }}^{-1}$ as a percentage of the total nitrogen existing in the initial slurry (\% $\mathrm{N}_{\mathrm{T}}$ slurry $)$, as a percentage of the $\mathrm{NH}_{4}^{+}$present in the initial slurry (\% $\mathrm{NH}_{4}^{+}$initial) and as a percentage of the total nitrogen existing in

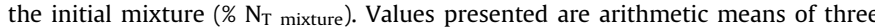
replicates. For each parameter, the means followed by different letters are significantly different with comparison in the Tukey test in each line.

\begin{tabular}{|c|c|c|c|c|c|}
\hline & \multicolumn{2}{|c|}{ Cumulated $\mathrm{N}_{2} \mathrm{O}-\mathrm{N}$} & \multicolumn{3}{|c|}{ Cumulated $\mathrm{NH}_{3}-\mathrm{N}$} \\
\hline & $\mu \mathrm{g} \mathrm{kg} \mathrm{kg}_{\text {mixture }}^{-1}$ & $\% \mathrm{~N}_{\mathrm{T} \text { mixture }}$ & $\mathrm{mg} \mathrm{kg}-1$ mixture & $\% \mathrm{NH}_{4}^{+}$initial slurry & $\% \mathrm{~N}_{\mathrm{T} \text { mixture }}$ \\
\hline CTRL & $5205.49^{a}$ & $0.21^{\mathrm{a}}$ & $931.69^{a}$ & $87.07^{a}$ & $38,18^{\mathrm{a}}$ \\
\hline ACID & $319.10^{d}$ & $0.01^{\mathrm{c}}$ & $3.65^{d}$ & $0.34^{\mathrm{e}}$ & $0,15^{\mathrm{d}}$ \\
\hline SUGAR & $152.63^{\mathrm{d}}$ & $0.01^{\mathrm{c}}$ & $507.46^{c}$ & $47.43^{c}$ & $20,80^{\mathrm{b}}$ \\
\hline WHEY & $2286.11^{c}$ & $0.12^{\mathrm{b}}$ & $296.72^{c}$ & $27.73^{\mathrm{d}}$ & $10,44^{\mathrm{c}}$ \\
\hline RICE & $4171.49^{b}$ & $0.11^{b}$ & $692.46^{\mathrm{b}}$ & $64.72^{\mathrm{b}}$ & $18,14^{\mathrm{b}}$ \\
\hline
\end{tabular}

with the $\mathrm{CH}_{4}$ emissions observed and reported below. In CTRL, the relationship between $\mathrm{N}_{2} \mathrm{O}$ and $\mathrm{CH}_{4}$ emissions was not clear, since the first peak of $\mathrm{N}_{2} \mathrm{O}$ emissions was not associated with any $\mathrm{CH}_{4}$ emissions. However, the increase of the $\mathrm{N}_{2} \mathrm{O}$ emissions in RICE, after day 47, occurred simultaneously with an increase of $\mathrm{CH}_{4}$ emissions. The higher $\mathrm{N}_{2} \mathrm{O}$ emissions observed in WHEY from day 30 onward can be attributed to: 1 ) the beginning of nitrification and denitrification processes since at that time frame the $\mathrm{pH}$ value of the mixture (cheese whey + slurry) had already increased and consequently the inhibitory effect of acidification on nitrification disappear (in agreement with the lower $\mathrm{NH}_{4}^{+}$content of CTRL slurry at the end of the experiment; 2 ) the surface crust formed in this treatment. The emission of $\mathrm{NH}_{3}$ in CTRL started to decrease when $\mathrm{N}_{2} \mathrm{O}$ emissions increased and the $\mathrm{N}_{2} \mathrm{O}$ peak observed in this treatment was reached on day 17 when $\mathrm{NH}_{3}$ emissions were null.

Considering the cumulative $\mathrm{N}_{2} \mathrm{O}$ emissions, the highest losses were observed in CTRL and RICE treatment, while losses of $\mathrm{N}_{2} \mathrm{O}-\mathrm{N}$ in ACID and SUGAR represented $0.01 \%$ each (Table 2 ). The acidification, as referred by Fangueiro et al. (2013) and Regueiro et al. (2016a), causes a delay on nitrification, explaining the lower concentration of nitrate and consequently decreasing the nitrous oxide emissions. It can then be concluded that bio-acidification of slurry using cheese whey or sugar allowed a reduction of total $\mathrm{N}_{2} \mathrm{O}$ emissions.

\subsubsection{Carbon dioxide emissions}

The $\mathrm{CO}_{2}$ emissions observed in each treatment did not follow a constant trend in all treatments during the experiment. Nevertheless, higher $\mathrm{CO}_{2}$ emissions were observed in RICE relative to all other treatments during the whole experiments (Fig. 4A). During the first three days of the experiment, $\mathrm{CO}_{2}$ emissions in SUGAR and WHEY treatments peaked at a value of 1.13 and $2.83 \mathrm{mg}$ $\mathrm{kg}_{\text {mixture }}^{-1} \mathrm{~h}^{-1}$ respectively. It is due to the fact that this new method of bio-acidification is based on microbial processes with an intense activity within the period where the slurry $\mathrm{pH}$ decrease (Dai and Blanes-Vidal, 2013). The CTRL and ACID kept a stable and lower rate almost throughout all experiment. After the first 12 days of trial, a decrease of $\mathrm{CO}_{2}$ emissions was observed in all treatments. However, during the second month of storage, the rice bran crust led to a significant increase of the $\mathrm{CO}_{2}$ emissions, with a peak on 

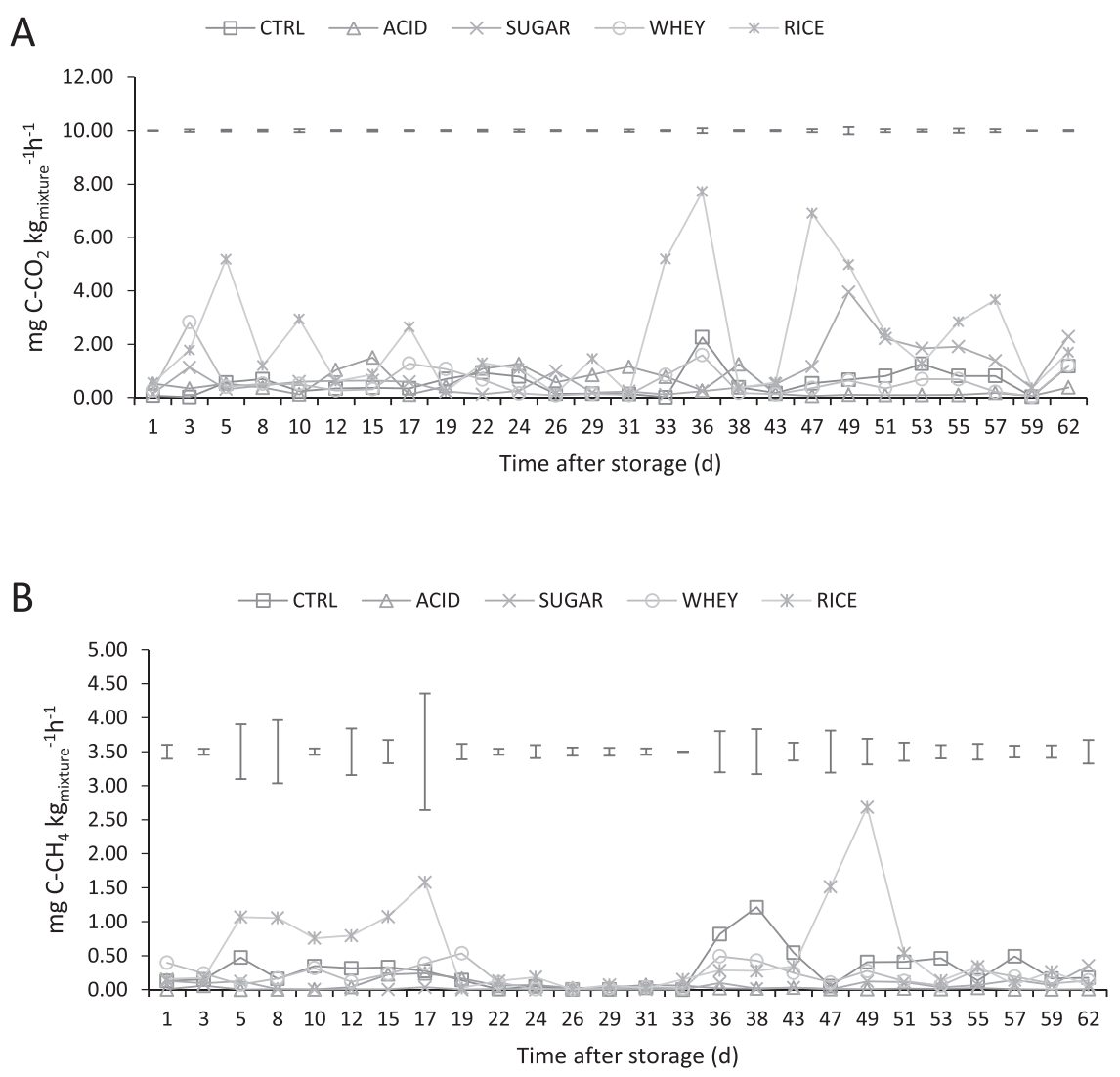

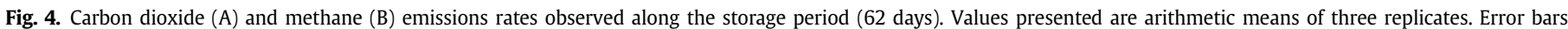
represent the standard error values used for comparison in the Tukey test at each sampling date.

Table 3

Cumulative amount of carbon dioxide and methane expressed per $\mathrm{kg}$ of mixture ( $\mathrm{g}$ $\left.\mathrm{kg}_{\text {mixture }}^{-1}\right)$ and as a percentage of the total carbon existing in the initial mixture $\left(\% \mathrm{C}_{\mathrm{T}}\right.$ mixture). Values presented are arithmetic means of three replicates. For each parameter, the means followed by different letters are significantly different with comparison in the Tukey test in each line.

\begin{tabular}{llllll}
\hline & \multicolumn{2}{l}{ Cumulated $\mathrm{CO}_{2}-\mathrm{C}$} & & \multicolumn{2}{l}{ Cumulated $\mathrm{CH}_{4}-\mathrm{C}$} \\
\cline { 2 - 3 } \cline { 5 - 6 } & $\mathrm{g} \mathrm{kg}$ mixture $^{-1}$ & $\% \mathrm{C}_{\mathrm{T} \text { mixture }}$ & & $\mathrm{g} \mathrm{kg}_{\text {mixture }}^{-1}$ & $\% \mathrm{C}_{\mathrm{T} \text { mixture }}$ \\
\hline CTRL & $0.81^{\mathrm{c}}$ & $3.66^{\mathrm{b}}$ & & $1.67^{\mathrm{b}}$ & $7.61^{\mathrm{a}}$ \\
ACID & $0.78^{\mathrm{c}}$ & $3.57^{\mathrm{b}}$ & & $0.24^{\mathrm{d}}$ & $1.09^{\mathrm{d}}$ \\
SUGAR & $1.22^{\mathrm{b}}$ & $3.17^{\mathrm{b}}$ & & $0.26^{\mathrm{d}}$ & $1.15^{\mathrm{d}}$ \\
WHEY & $0.84^{\mathrm{c}}$ & $1.98^{\mathrm{c}}$ & & $1.03^{\mathrm{c}}$ & $2.41^{\mathrm{c}}$ \\
RICE & $3.29^{\mathrm{a}}$ & $5.34^{\mathrm{a}}$ & & $2.84^{\mathrm{a}}$ & $4.61^{\mathrm{b}}$ \\
\hline
\end{tabular}

days 36 (7.72 $\mathrm{mg} \mathrm{kg}_{\text {mixture }}^{-1}$ ), 47 (6.90 $\left.\mathrm{mg} \mathrm{kg}_{\text {mixture }}{ }^{1} \mathrm{~h}^{-1}\right)$ and 57 (3.67 $\mathrm{mg} \mathrm{kg}_{\text {mixture }}{ }^{-1} \mathrm{~h}^{-1}$ ).

Despite the differences observed on the daily $\mathrm{CO}_{2}$ emissions, no significant differences were observed in CTRL, ACID and WHEY regarding the total $\mathrm{CO}_{2}-\mathrm{C}$ emitted expressed per $\mathrm{kg}$ of the total material in the jar (Table 3). Attending the fact that the own additives may release some carbon, both total $\mathrm{CO}_{2}$ and $\mathrm{CH}_{4}$ emissions were expressed as \% of the total amount of $\mathrm{C}$ existing in the initial mixture (including additives).

As can be seen in Table 1, the rice bran increased the carbon and organic $\mathrm{N}$ content of the mixture compared to the raw slurry, which results in a higher cumulative loss of $\mathrm{CO}_{2}-\mathrm{C}$. Furthermore, the intense release of $\mathrm{CO}_{2}$ from this treatment might be due to the occurrence of aerobic degradation of organic matter. This led to an increase in emissions, which had an impact in the cumulated value emitted that was higher than in the non-treated slurry but corresponded to only $5 \%$ of the total initial $\mathrm{C}$ of the mixture. The amount of initial $\mathrm{C}$ lost as $\mathrm{CO}_{2}$ in CTRL and ACID were similar $(\sim 3.4 \%)$ and significantly lower than in all other treatments.

The only treatments that kept a lower emission of $\mathrm{CO}_{2}$ than in CTRL along the experiment were ACID and WHEY (Table 3). Previous studies done in a short time frame showed no effect of acidification with sulphuric acid on $\mathrm{CO}_{2}$ emissions (Dai e BlanesVidal, 2013), as observed here, but in other studies where slurry fractions where separated and acidified, the acidification had an average reduction of $51 \%$ on $\mathrm{CO}_{2}$ emissions during the first 30 days of storage (Regueiro et al., 2016b).

\subsubsection{Methane emission}

Methane emissions remained residual in ACID during all the experiment and were always lower or similar to CTRL. The results obtained here are in agreement with those reported by other authors that observed a reduction of methane emission with slurry acidification during storage from 67 to 87\% (Petersen et al., 2014). Slurry acidification with sulphuric acid is known to inhibit the methanogens bacteria (Guo et al., 2020) reason why we observed a lower and constant $\mathrm{CH}_{4}$ emission rate relative to CTRL (Fig. 4B). Such effect of $\mathrm{H}_{2} \mathrm{SO}_{4}$ on methanogens bacteria was attributed to the accumulation of sulphite (Petersen et al., 2014). Nevertheless, the bio-acidification using sugar led also to residual $\mathrm{CH}_{4}$ emissions as in ACID.

The emission of $\mathrm{CH} 4$ occurred under anaerobic conditions (Hansen et al., 2006) while the $\mathrm{CO}_{2}$ occur mostly in aerobic conditions (Moset et al., 2012). Hence when $\mathrm{CO}_{2}$ emissions are 
Table 4

Total GHG emissions observed in each treatment (slurry + treatment) and the relative contribution of each gas. The values presented are arithmetic means of three replicates. For each parameter, the means followed by different letters are significantly different with comparison in the Tukey test in each line.

\begin{tabular}{|c|c|c|c|}
\hline & $\begin{array}{l}\text { Total GHG emissions } \\
\text { ( } \mathrm{g} \mathrm{CO}_{2} \text { Eq. } \mathrm{kg}^{-1} \text { mixture) }\end{array}$ & $\% \mathrm{~N}_{2} \mathrm{O}$ & $\% \mathrm{CH}_{4}$ \\
\hline CTRL & $133,52^{b}$ & 6,49 & 93,51 \\
\hline ACID & $41,55^{c}$ & 1,28 & 98,72 \\
\hline SUGAR & $19,78^{\mathrm{d}}$ & 1,37 & 98,63 \\
\hline WHEY & $121,58^{\mathrm{b}}$ & 4,70 & 95,30 \\
\hline RICE & $249,61^{a}$ & 3,06 & 96,94 \\
\hline
\end{tabular}

observed, significant methane emissions are not expected. However, the rice bran crust led to emissions of both $\mathrm{CO}_{2}$ and $\mathrm{CH}_{4}$ even if at an inconstant rate (Fig. 4B). It is to note that in RICE, $\mathrm{C}$ losses by $\mathrm{CO}_{2}$ emissions $\left(5.34 \%\right.$ of $\mathrm{C}_{\text {Tmixture }}$ ) are close to $\mathrm{C}$ losses by $\mathrm{CH}_{4}$ emissions (4.61\% of $\mathrm{C}_{\mathrm{T}}$ mixture) (Table 3 ). The same occurred in WHEY with $\sim 2 \%$ of $\mathrm{C}_{\mathrm{T}}$ mixture lost by $\mathrm{CO}_{2}$ and $2.4 \%$ lost by $\mathrm{CH}_{4}$.

The main concern relative to sucrose addition to the slurry is a potential increase of $C$ losses, namely as methane. However, no difference was observed between ACID and SUGAR, in terms of cumulated $\mathrm{CH}_{4}$ emissions ( $\sim 1 \% \mathrm{C}_{\mathrm{T}}$ mixture). The values observed relative to ACID were similar to the results obtained by the authors Sokolov et al. (2020).

\subsubsection{Total GHG emissions}

The total GHG emissions expressed as $\mathrm{CO}_{2}$ equivalent was calculated from the cumulated emissions of $\mathrm{CH}_{4}$ and $\mathrm{N}_{2} \mathrm{O}$.

Our results showed that slurry acidification with sulphuric acid decreased not only $\mathrm{NH}_{3}$ emissions relative to CTRL but also the total GHG emissions in $70 \%$ (Table 4). Sugar addition to slurry significantly decreased the total GHG emissions (in $~ 85 \%$ ) relative to CTRL. However, slurry treatment with cheese whey led to total GHG emissions similar to those observed in CTRL. As expected, the rice bran crust had higher GHG emissions, $186 \%$ higher than in the CTRL (Table 4). In all treatments, the main contributor to total GHG emissions was methane while the contribution of $\mathrm{N}_{2} \mathrm{O}$ was always lower than $7 \%$.

The acidification with sulphuric acid and bio-acidification with sugar seem to be a good option to adopt in order to decrease the total GHG emitted. The higher value observed on the RICE was due to the richest content in carbon, which discarded this treatment to the reduction of GHG emissions.

\subsection{The technical and economic viability of the solutions proposed}

The two materials (cheese whey and rice bran) tested here as an alternative to sulphuric acid are available in large amounts in regions producing cheese and rice. Furthermore, both the cheese whey and the rice bran have no commercial value in Portugal, and it will be speculative to attribute any commercial price to these materials. It is therefore impossible to accurately compare the costs associated with these new solutions with the sulphuric acid that has an actual commercial cost of 0.4 Euros per litre (Liu et al., 2019). The use of cheese whey and rice bran can be seen as a win-win situation where the producers will save some money by avoiding the cost associated to treatment and transport of these materials to landfill while farmers will be able to minimize ammonia losses from storage and even enrich the slurry with some nutrients.

The use of sugar is a good alternative to acid considering the relatively low value of this material varying from 0.24 to 0.28 Euros per $\mathrm{kg}$ (Indexmundi, 2020). Nevertheless, $40 \mathrm{~kg}$ of sugar $(\sim 10$ Euros) are needed to acidify one tonne of slurry against $6 \mathrm{~L}$ of concentrated acid (2.4 Euros). Hence, the main idea is to replace sugar by a sucrose source with no commercial value.

The amount of additive is, in some treatments, considerable and might lead to an increase of the effluent volumes to be applied. However, some of these additives are rich in nutrients and will improve the fertilizer value of the treated slurry.

\section{Conclusion}

The use of sulphuric acid as shown to be an optimal solution to be adopted for slurry management. The use of sugar for bioacidification may appear to be a good alternative to ACID even if less efficient to reduce $\mathrm{NH}_{3}$ emissions but more effective in the reduction of GHG emissions. WHEY reduces in 58\% of the ammonia emissions but emitted the same amount of GHG as CTRL. It might then also be considered as an additive for bio-acidification when the main concern is ammonia emissions. The use of rice bran as an additive to reduce $\mathrm{NH}_{3}$ and GHG emissions is not a solution even if it increases the fertilizer value of slurry in terms of $\mathrm{N}, \mathrm{P}$ and $\mathrm{K}$. It can then be concluded that both the cheese whey as well as the sugar addition to slurry have a good potential as a slurry additive to reduce $\mathrm{NH}_{3}$ emissions. Namely, the cheese whey that also contains some nitrogen allows to keep the $\mathrm{N}$ content in the mixture slurry:cheese whey at the value observed initially in the slurry. More experiments at a larger scale are needed to validate our findings.

\section{Declaration of competing interest}

The authors declare the following financial interests/personal relationships which may be considered as potential competing interests: This work was supported by the Nutri2Cycle project (grant agreement $\mathrm{N}^{\circ}$ 773682) funded by the European Union's Horizon 2020 research and innovation programme and National Funds from FCT - Portuguese Foundation for Science and Technology, under the project PEST/UID/AGR/4131 and PTDC/ASP-SOL/ 28769/2017 "Animal slurry hygienization for use in industrial horticulture". This document reflects only the author's view and the Union is not liable for any use that may be made of the information contained therein.

\section{CRediT authorship contribution statement}

Joana Prado: Conceptualization, Data curation, Formal analysis, Investigation, Methodology, Writing - original draft, Writing - review \& editing. João Chieppe: Data curation, Formal analysis, Methodology, Writing - original draft, Writing - review \& editing. Anabela Raymundo: Conceptualization, Formal analysis, Investigation, Methodology, Resources, Validation, Writing - original draft, Writing - review \& editing. David Fangueiro: Conceptualization, Formal analysis, Funding acquisition, Investigation, Methodology, Project administration, Resources, Supervision, Validation, Writing - original draft, Writing - review \& editing.

\section{Acknowledgements}

This work was supported by the Nutri2Cycle project funded by the European Union's Horizon 2020 research and innovation programme (grant agreement $\mathrm{N}^{\circ}$ 773682) and Portuguese Funds from FCT - Portuguese Foundation for Science and Technology, under the project PEST/UID/AGR/4131 and PTDC/ASP-SOL/28769/2017 "Animal slurry hygienization for use in industrial horticulture". This document reflects only the author's view and the Union is not liable for any use that may be made of the information contained therein. The authors thank the three reviewers for their excellent revision of the manuscript and constructive suggestions. 


\section{References}

Adegbeye, M.J., Elghandour, M.M.M.Y., Monroy, J.C., Abegunde, T.O., Salem, A.Z.M., Barbabosa-Pliego, A., Faniyi, T.O., 2019. Potential influence of Yucca extract as feed additive on greenhouse gases emission for a cleaner livestock and aquaculture farming - a review. J. Clean. Prod. 239, 118074. https://doi.org/10.1016/ j.jclepro.2019.118074.

Alexandratos, N., Bruinsma, J., 2012. World Agriculture towards 2030/2050: the 2012 Revision. FAO, Rome.

Amon, B., KryvoruchkoV, A., Amon, T., Zechmeister-Boltenstern, S., 2006. Methane, nitrous oxide and ammonia emissions during storage and after application of dairy cattle slurry and influence of slurry treatment. Agric. Ecosyst. Environ. 112, 153-162. https://doi.org/10.1016/j.agee.2005.08.030.

Anderson, N., Strader, R., Davidson, C., 2003. Airborne reduced nitrogen: ammonia emissions from agriculture and other sources. Environ. Int. 29, 277-286. https://doi.org/10.1016/S0160-4120(02)00186-1.

Berg, W., Brunsch, R., Pazsiczki, I., 2006. Greenhouse gas emissions from covered slurry compared with uncovered during storage. Agric. Ecosyst. Environ. 112 129-134. https://doi.org/10.1016/j.agee.2005.08.031.

Dai, X.R., Blanes-Vidal, V., 2013. Emissions of ammonia, carbon dioxide, and hydrogen sulfide from swine wastewater during and after acidification treatment: effect of pH, mixing and aeration. J. Environ. Manag. 115, 147-154. https://doi.org/10.1016/j.jenvman.2012.11.019.

Eise, J., Foster, K., 2009. Global agriculture towards 2050, how to feed the world. Expert Forum. https://doi.org/10.5822/978-1-61091-885-5.

Fangueiro, D., Coutinho, J., Chadwick, D., Moreira, N., Trindade, H., 2008. Effect of cattle slurry separation on greenhouse gas and ammonia emissions during storage. J. Environ. Qual. 37, 2322. https://doi.org/10.2134/jeq2007.0330.

Fangueiro, D., Hjorth, M., Gioelli, F., 2015a. Acidification of animal slurry-a review. J. Environ. Manag. 149, 46-56. https://doi.org/10.1016/j.jenvman.2014.10.001.

Fangueiro, D., Pereira, J., Bichana, A., Surgy, S., Cabral, F., Coutinho, J., 2015b. Effects of cattle- slurry treatment by acidification and separation on nitrogen dynamics and global warming potential after surface application to an acidic soil. J. Environ. Manag. 1-8. https://doi.org/10.1016/j.jenvman.2015.07.032.

Fangueiro, D., Surgy, S., Coutinho, J., Vasconcelos, E., 2013. Impact of cattle slurry acidification on carbon and nitrogen dynamics during storage and after soil incorporation. J. Plant Nutr. Soil Sci. 176, 540-550. https://doi.org/10.1002/ jpln.201200117.

Fangueiro, D., Surgy, S., Fraga, I, Vasconcelos, E.,2015c. In: Acid Treatment of Animal Slurries: Potential and Limitations, vol. 775. International Fertiliser Society, United Kingdom, p. 24

Faostat, 2015a. FAO - food and agricultural organization of the united nations [WWW document]. URL. http://faostat3.fao.org/browse/Q/QP/E. accessed 5.5.19.

Faostat, 2015b. FAO - food and agricultural organization of the united nationsdairy production and products: milk production [WWW document]. URL http://www.fao.org/agriculture/dairy-gateway/milk-production/en/ \#.V3zgRDVu3fZ. accessed 5.5.19.

Gerber, P.J., Steinfeld, H., Henderson, B., Mottet, A., Opio, C., Dijkman, J., Falcucci, A Tempio, G., 2013. Tackling Climate Change through Livestock: A Global Assessment of Emissions and Mitigation Opportunities. FAO, Rome.

Guo, G., Chen, Y., Tian, F., Gao, Z., Zhu, C., Liu, C., 2020. Effects of livestock manure properties and temperature on the methanogen community composition and methane production during storage. Environ. Technol. 41, 131-140. https:/ doi.org/10.1080/09593330.2018.1491640.

Hansen, M.N., Henriksen, K., Sommer, S., 2006. Observations of production and emission of greenhouse gases and ammonia during storage of solids separated from pig slurry: effects of covering. Atmos. Environ. 40, 4172-4181. https:// doi.org/10.1016/j.atmosenv.2006.02.013.

Hassouna, M., Eglin, T., Cellier, P., Colomb, V Cohan, J., Decug C., Delabuis, M Edouard, N., Espagnol, S., Eugène, M., 2017. Measuring Emissions from Livestock Farming : Greenhouse Gases, Ammonia and Nitrogen Oxides to Cite This Version: HAL Id : Hal-01567208. INRA-ADEME.

Hou, Y., Velthof, G.L., Lesschen, J.P., Staritsky, I.G., Oenema, O., 2017. Nutrient recovery and emissions of ammonia, nitrous oxide, and methane from animal manure in Europe: effects of manure treatment technologies. Environ. Sci. Technol. 51, 375-383. https://doi.org/10.1021/acs.est.6b04524.

Houba, V.J.G., Temminghoff, E.J.M., Gaikhorst, G.A., van Vark, W., 2000. Soil analysis procedures using $0.01 \mathrm{M}$ calcium chloride as extraction reagent. Commun. Soil Sci. Plant Anal. 31, 1299-1396. https://doi.org/10.1080/00103620009370514.

Indexmundi, 2020. Sugar monthly price [WWW document]. URL. https://www. indexmundi.com/commodities/?commodity=sugar\&amp;months=60\&amp; currency=eur. accessed 3.19.20.

International Panel Climate Change, 2016. Global Warming Potential Values. Fifth Assesment 2014, pp. 2-5.

Kai, P., Pedersen, P., Jensen, J.E., Hansen, M.N., Sommer, S.G., 2008. A whole-farm assessment of the efficacy of slurry acidification in reducing ammonia emissions. Eur. J. Agron. 28, 148-154. https://doi.org/10.1016/j.eja.2007.06.004.

Krause, A., Rotter, V., 2018. Recycling improves soil fertility management in smallholdings in Tanzania. Agriculture 8, 31. https://doi.org/10.3390/ agriculture 8030031

Leip, A., Billen, G., Garnier, J., Grizzetti, B., Lassaletta, L., Reis, S., Simpson, D., Sutton, M.A., De Vries, W., Weiss, F., Westhoek, H., 2015. Impacts of European livestock production: nitrogen, sulphur, phosphorus and greenhouse gas emissions, land-use, water eutrophication and biodiversity. Environ. Res. Lett. 10, 115004. https://doi.org/10.1088/1748-9326/10/11/115004.

Liu, J.N., de Neergaard, A., Jensen, L.S., 2019. Increased retention of available nitrogen during thermal drying of solids of digested sewage sludge and manure by acid and zeolite addition. Waste Manag. 100, 306-317. https://doi.org/ 10.1016/j.wasman.2019.09.019.

Loyon, L., Guiziou, F., Beline, F., Peu, P., 2007. Gaseous Emissions $\left(\mathrm{NH}_{3}, \mathrm{~N}_{2} \mathrm{O}, \mathrm{CH}_{4}\right.$ and $\mathrm{CO}_{2}$ ) from the aerobic treatment of piggery slurry-Comparison with a conventional storage system. Biosyst. Eng. 97, 472-480. https://oi.org/10.1016/ j.biosystemseng.2007.03.030.

Malaspina, F., Stante, L., Cellamare, C.M., Tilche, A., 1995. Cheese whey and Cheese factory wastewater treatment with a biological anaerobic - aerobic process. Water Sci. Technol. 32, 59-72. https://doi.org/10.2166/wst.1995.0459.

Malomo, G.A., Madugu, A.S., Bolu, S.A., 2018. Sustainable animal manure management strategies and practices. In: Agricultural Waste and Residues, pp. 119-137. https://doi.org/10.5772/intechopen.78645.

Maroušek, J., StruneckýO, Stehel, V., 2019. Biochar farming: defining economically perspective applications. Clean Technol. Environ. Policy 21, 1389-1395. https:// doi.org/10.1007/s10098-019-01728-7.

Misselbrook, T., Hunt, J., Perazzolo, F., Provolo, G., 2016. Greenhouse gas and ammonia emissions from slurry storage: impacts of temperature and potential mitigation through covering (pig slurry) or acidification (cattle slurry). J. Environ. Qual. 45, 1520-1530. https://doi.org/10.2134/jeq2015.12.0618.

Moset, V., Cambra-López, M., Estellés, F., Torres, A.G., Cerisuelo, A., 2012. Evolution of chemical composition and gas emissions from aged pig slurry during outdoor storage with and without prior solid separation. Biosyst. Eng. 111, 2-10. https:// doi.org/10.1016/j.biosystemseng.2011.10.001.

Ni, J.Q., 1999. Mechanistic models of ammonia release from liquid manure: a review. J. Agric. Eng. Res. 72, 1-17. https://doi.org/10.1006/jaer.1998.0342.

Pereira, E., Einloft, S., Seferin, M., dos Santos, L.M., Lima, J., Ligabue, R., 2019. Enzymatic degradation of the rice bran: problem or opportunity? Waste Biomass Valorization 10, 755-762. https://doi.org/10.1007/s12649-017-9995-9.

Petersen, S.O., 2018. Greenhouse gas emissions from liquid dairy manure: prediction and mitigation. J. Dairy Sci. 101, 6642-6654. https://doi.org/10.3168/ jds.2017-13301.

Petersen, S.O., Andersen, A.J., Eriksen, J., 2012. Effects of cattle slurry acidification on ammonia and methane evolution during storage. J. Environ. Qual. 41, 88. https://doi.org/10.2134/jeq2011.0184.

Petersen, S.O., Højberg, O., Poulsen, M., Schwab, C., Eriksen, J., 2014. Methanogenic community changes, and emissions of methane and other gases, during storage of acidified and untreated pig slurry. J. Appl. Microbiol. 117, 160-172. https:/| doi.org/10.1111/jam.12498.

Piveteau, S., Picard, S., Dabert, P., Daumer, M.L., 2017. Dissolution of particulate phosphorus in pig slurry through biological acidification: a critical step for maximum phosphorus recovery as struvite. Water Res. 124, 693-701. https:// doi.org/10.1016/j.watres.2017.08.017.

Regueiro, I., Coutinho, J., Fangueiro, D., 2016a. Alternatives to sulfuric acid for slurry acidification: impact on slurry composition and ammonia emissions during storage. J. Clean. Prod. 131, 296-307. https://doi.org/10.1016/ j.jclepro.2016.05.032.

Regueiro, I. Coutinho, J. Gioelli, F, Balsari, P. Dinuccio, E, Fangueiro, D. 2016b. Acidification of raw and co-digested pig slurries with alum before mechanical separation reduces gaseous emission during storage of solid and liquid fractions. Agric. Ecosyst. Environ. 227, 42-51. https://doi.org/10.1016/ j.agee.2016.04.016.

Rodhe, L., Casimir, J., Sindhöj, E., 2018. Possibilities and Bottlenecks for Implementing Slurry Acidification Techniques in the Baltic Sea Region doi:978-9188695-11-6.

Schmidt, H.-P., 2014. Treating liquid manure with biochar. Biochar J 1, 273-276.

Sokolov, V.K., VanderZaag, A., Habtewold, J., Dunfield, K., Wagner-Riddle, C., Venkiteswaran, J.J., Crolla, A., Gordon, R., 2020. Dairy manure acidification reduces $\mathrm{CH}_{4}$ emissions over short and long-term. Environ. Technol. 1-9. https:// doi.org/10.1080/09593330.2020.1714744.

UN, 2013. World Population Projected to Reach 9.6 Billion by 2050 [WWW Document]. United Nations Dep. Econ. Soc. Aff. URL. http://www.un.org/en/ development/desa/news/population/un-report-world-population-projectedto-reach-9-6-billion-by-2050.html. accessed 4.3.19.

Van der Zaag, A.C., Gordon, R.J., Glass, V.M., Jamieson, R.C., 2008. Floating covers to reduce gas emissions from liquid manure storages: a review. Appl. Eng. Agric. 24, 657-671. https://doi.org/10.13031/2013.25273.

Wang, K., Huang, D., Ying, H., Luo, H., 2014. Effects of acidification during storage on emissions of methane, ammonia, and hydrogen sulfide from digested pig slurry. Biosyst. Eng. 122, 23-30. https://doi.org/10.1016/j.biosystemseng.2014.03.002.

Wright, I.A., Tarawali, S., Blummel, M., Gerard, B., Teufel, N., Herrero, M., 2012. Integrating crops and livestock in subtropical agricultural systems. J. Sci. Food Agric. 92, 1010-1015. https://doi.org/10.1002/jsfa.4556. 